\title{
Ja, selvfølgelig, men
}

\section{En note om Derridas reservation over for det politiske engagement}

Selv med den bedste vilje i verden, med den mest oprigtige moralske indignation over noget, der faktisk er uudholdeligt og uantageligt, ville man måske komme til at fængsle det igen, som man ønskede at befri. (Derrida 2007: 97)

Jeg begynder med et citat om det komplicerede i at engagere sig til fordel for en sag. Det er Derrida. Han skriver linjerne i et brev til den franske forfatter og tidligere trækkerdreng Jean Genet. Brevet er dateret den 20. august 1971. ${ }^{\mathrm{I}}$ Genet var på det tidspunkt i fuld sving med at mobilisere den franske intellektuelle offentlighed til fordel for George Jackson, en 28-årig afrikansk-amerikaner som var anklaget for at have dræbt en fængselsbetjent i Soledad Correctional Training Facility i Californien. Jacksons sag var på forsiderne i såvel USA som Frankrig. Genet var allerede involveret og havde året før skrevet forordet til den franske oversættelse af de breve, som Jackson havde samlet i bogen Soledad Brothers: The Prison Letters of George Jackson.

Derrida var ikke i tvivl om det rigtige i Jacksons kamp og havde således signeret den støtteerklæring, som Genet havde udfærdiget, "Appel pour un comité de soutien aux militants politiques noirs emprisonnés". Derrida var enig i, at USA's afrikansk-amerikanere kæmpede en retfærdig kamp mod undertrykkelse og racisme. Men han var ikke sikker på, at det var det rigtige at stille sig op sammen med Genet og andre franske intellektuelle og tale Jacksons sag. Risikerer man ikke dermed at tale på vegne af ham, som netop var blevet frarøvet en stemme, og således bekræfte den underkastelse, som Genets appel var rettet imod i første omgang? Blev Jackson ikke fastholdt i en underkastet position, hvis Genet og Derrida gik ud i en fransk offentlighed og råbte op om afrikansk-amerikanernes ofre? Det var ikke fordi, Derrida ikke var enig med Genet i det horrible og uretfærdige ved Jacksons sag, men Derrida var simpelthen bange for, at han, i fald han engagerede sig til fordel for Jackson gennem Genets appel, ville reproducere selve den undertrykkelsesstruktur, som appellen jo var intenderet som en kritik af. Ja, selvfølgelig, men... 
For Genet var Jackson først og fremmest en sort revolutionær, som kæmpede for sin frihed. Men Jackson var samtidig digter. Som Genet skriver i sin introduktion til brevene: "Fra det første brev til det sidste er intet blevet villet, skrevet eller komponeret for en bogs skyld, ikke desto mindre er der en bog hér, hård og sikker, både et frihedsvåben og et kærlighedsdigt" (Genet i Jackson: 2). I brevene, som dækker årene fra 1965 til 1970, redegør Jackson for det umenneskelige liv i fængslet og kritiserer med stor energi og potent vrede det racistiske USA. Bogen gjorde Jackson til et ikon i den sorte modstandskamp mod racisme og undertrykkelse.

Black Panther Party havde siden 1966 arbejdet for retten til sort selvforsvar konfronteret med den udbredte racisme og forskelsbehandling, der var en realitet i USA på dette tidspunkt. Jacksons breve var blot endnu et bevis i en lang række på de store problemer, der truede med at sprænge USA i luften i årene sidst i 1960'erne og begyndelsen af 1970'erne: racisme og de dertil knyttede borgerrettighedskampe, studenteroprør, riots og Vietnamkrigen, alle disse begivenheder truede med at brække landet midt over. At staten udelukkende forholdt sig repressivt til uroen, gjorde ikke sagen bedre. Den hårdhændede fremfærd mod de sorte pantere, som gentagne gange blev overfaldet og beskudt af politiet og udsat for FBI's infiltrationsforsøg, stod som mønstereksempel på en stadigt mere autoritær statsmagt. ${ }^{2}$

George Jackson var oprindeligt blevet dømt til ét års fængsel for at have stjålet 71 dollars fra en tankstation i 1960. ${ }^{3}$ Dommen var imidlertid hvert år blevet forlænget, og i 1971 havde han således tilbragt ti år i fængsel. I løbet af denne periode begyndte Jackson at studere politiske tekster af bl.a. Mao, Frantz Fanon og Fidel Castro og fors $\varnothing$ gte at uddanne sig selv og sine medfangere til revolutionære snarere

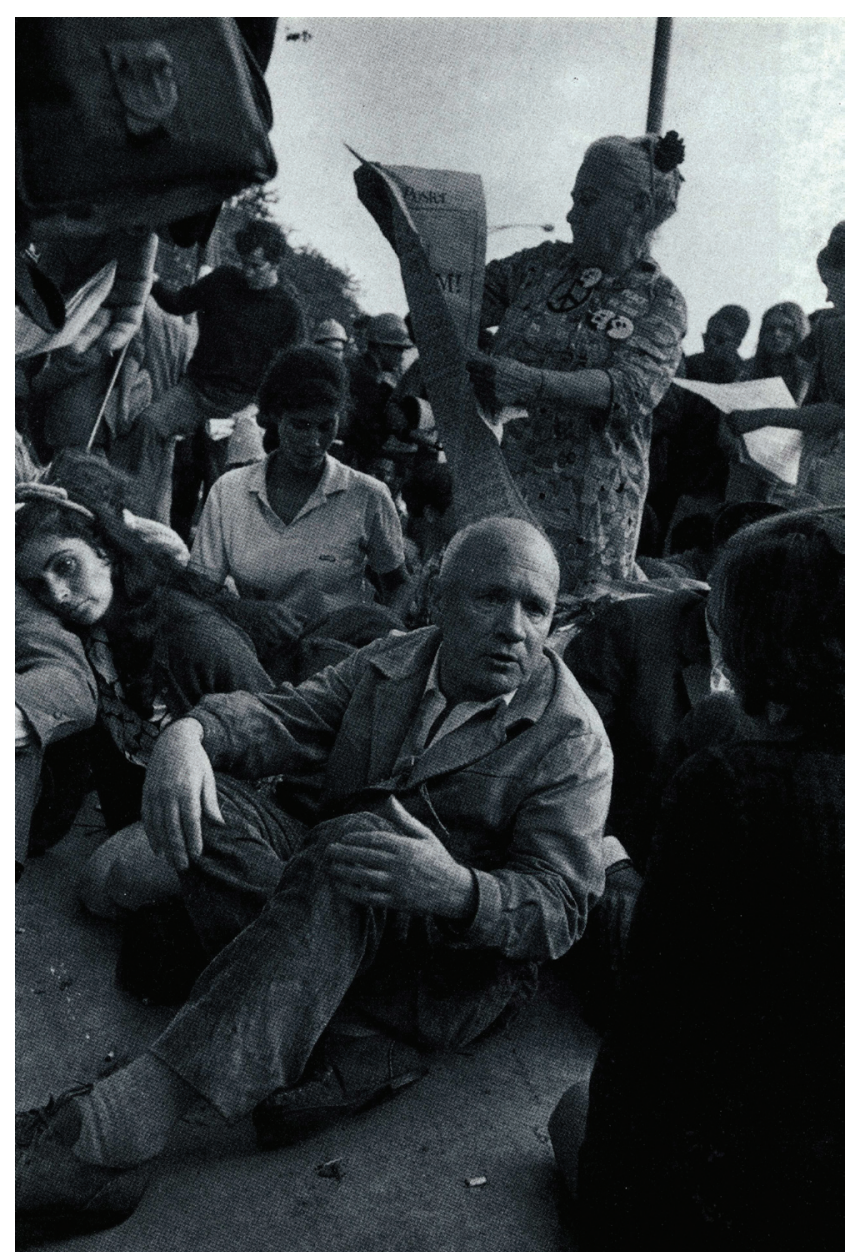

Jean Genet til en demonstration mod Vietnam-krigen i Chicago, 1968 
Derrida deltager i en konference om immigranters ret til at stemme i Maison de la Mutualité, Paris, 1989.

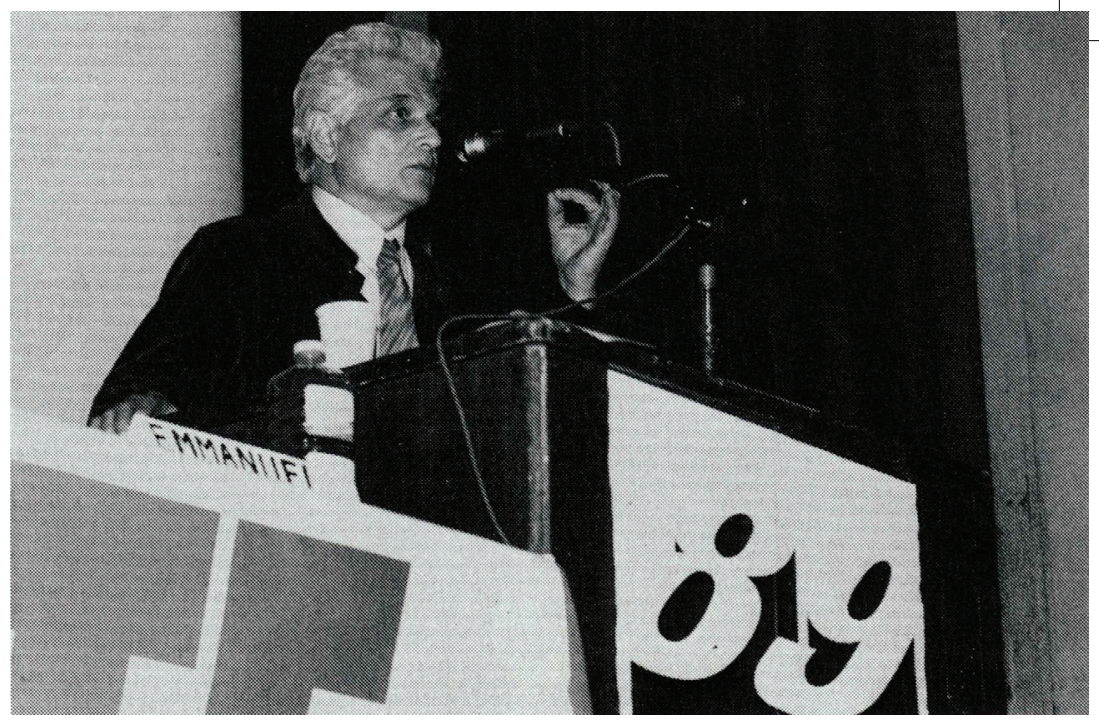

end blot kriminelle. Fængselsledelsen så med bekymring på Jacksons radikalisering, og i årevis sad han isolationsfængslet. Efter en notorisk racistisk fængselsvagt, O. G. Miller, havde skudt tre afrikansk-amerikanske fanger i Soledad og var blevet frikendt ved den efterfølgende retssag, blev en anden hvid fængselsbetjent, John V. Mills, overfaldet af indsatte og dræbt. Ifølge anklagemyndigheden stod Jackson og to andre fanger bag drabet. Hvis de blev dømt, kunne de risikere dødsstraf. Det var denne sag, som Genet havde engageret sig i. Genet ville i al hast, før retssagen gik i gang, oprette en komité, der skulle støtte Jackson og de afrikansk-amerikanske fangers kamp. Det var derfor, Genet havde henvendt sig til Derrida såvel som til andre franske intellektuelle og forfattere som Roland Barthes, Maurice Blanchot, Marguerite Duras, Dionys Mascolo og Philippe Sollers og bedt dem om at signere en støtteerklæring: "De undertegnede intellektuelle [...] protesterer mod den amerikanske regerings stadigt mere intense undertrykkelse af den sorte bevægelse og forlanger løsladelse af alle de politiske fanger øjeblikkeligt" (Genet: 96). Det var desuden Genets plan at udgive en bog, hvor medunderskriverne bidrog med en tekst.

Genet var voldsomt engageret i sagen. I marts 1970 var han rejst illegalt til USA inviteret af Black Panther Party og havde gennem to måneder holdt foredrag rundt omkring i landet, hvor han opfordrede hvide studerende og arbejdere til at støtte afrikansk-amerikanere i deres kamp mod, hvad Genet betegnede som et korrupt og racistisk USA. ${ }^{4}$ Genet lagde ikke fingrene imellem, men forsvarede afrikanskamerikanernes ret til selvforsvar. "Det er på mode at beskylde Black Panther Party for at bruge vold, men hvide amerikanere har været voldelige mod sorte i mere end to hundrede år. Hvordan havde du regnet med, at panterne ville reagere?" (Genet citeret i Sandarg: 274). Det var tid til at sige fra og gå på gaden. Modstanden mod Vietnam-krigen var vigtig, men den skulle forbindes til kampen mod racisme i USA internt.

I 1970 var Jean Genet et kendt navn i såvel Frankrig som USA. Den skandaleombruste forfatter og dramatiker havde siden slutningen af 1940'erne udfordret den kulturelle offentlighed med sine autobiografiske romaner om homoseksuelle transgressioner og gennem skuespil, hvor underkastede hævner sig ved at tage livet af deres undertrykkere. Genets skuespil var del af en ny bølge inden for teateret, som Martin Esslin kalder "det absurde teater", som udfordrede publikum med menings- 


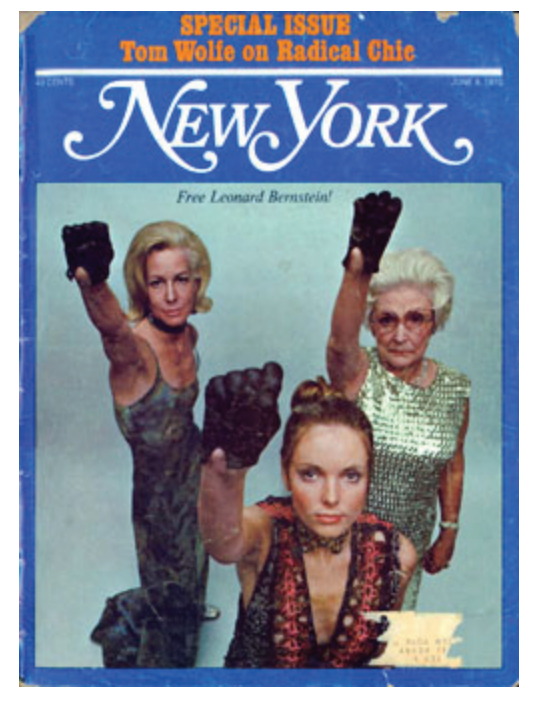

Forsiden på New York Magazine, juni 1970, hvori Tom Wolfes "Radical Chic: That Party at Lenny's" var trykt.

løse handlinger, non sequitur humor og et usammenhængende sprog. Genet fremstillede den moderne verden som grotesk og inhuman, som en mellemting mellem mareridt og farce, hvor obskøniteter og erotisk ømhed smeltede sammen i en ustabil blanding, som når fængslets lortebefængte hul danner ramme for englens rene lys, eller når ekskrementer udstyres med en næsten himmelsk skønhed. Såvel Genets autobiografier som hans skuespil besad en veritabel chokværdi på dette tidspunkt; den amerikanske premiere på Les nègres i 1961, hvor sorte gennemspiller en voldelig revolte mod hvide for et hvidt publikum iscenesat af en hvid dramatiker, vakte skandale i New York og dramatiserede den udbredte racediskrimination, som var et af tidens mest sprængfarlige emner. I 1966 forholdt Genet sig til endnu en ømtålelig situation, da han i Les paravents bidende kritisk skildrede fransk tilstedeværelse i Algeriet blot få år efter afslutningen på den smertefulde borgerkrig. Selvom Genet fastholdt, at han ikke var interesseret i sine karakterers sociale problemer, blev hans værker i stigende grad politiske, og efter Maj' 68, hvor Genet offentligt støttede den tysk fødte studenteraktivist Daniel Cohn-Bendit, som blev udvist fra Frankrig efter studenteroprøret, kastede han sig med stor energi ud i politiske kampe og identificerede sig med de undertrykte og deres revolutionære perspektiv. Kunstens og teatrets lille verden, som Genet på én og samme tid nærede afsky for og var del af, blev udvidet først med afrikansk-amerikanernes og siden senere i 1970'erne med palæstinensernes frihedskamp.

Genets støtte til panterne kom på et tidspunkt, hvor Black Panther Party kæmpede en hård kamp mod overmagten. Politiet for hårdt frem - i 1969 alene blev 348 medlemmer arresteret for alvorlige forbrydelser, og organisationen betalte samme år mere end fem millioner dollars i kaution - og bevægelsen havde svært ved at håndtere repressionen, der indadtil udviklede sig til mistænksomhed, kynisme og splittelse. Der begyndte at opstå konkurrerende fløje: En fraktion ville satse på militant modstand, en anden på socialt arbejde. Den kendte franske forfatters uforbeholdne støtte var en hårdt tiltrængt håndsrækning. Genet pegede på det legitime i panternes kamp: Det var en frihedskamp, der ikke var ulig den, det algeriske folk havde kæmpet mod den franske kolonimagt sidst i 1950'erne og i begyndelsen af 1960'erne. Men Genets engagement til fordel for afrikansk-amerikanerne truede samtidig med at gøre modstandskampen fashionabel, gøre den til et symbol på 
systemintern coolness, der intet havde med revolution eller antikolonialistisk kamp at gøre. Det var i al fald den amerikanske forfatter og pulpjournalist Tom Wolfes analyse. Han ironiserede over denne mulige konsekvens af Genets og andre kulturpersonligheders støtte til Black Panther Party i en serie artikler i New York Magazine publiceret i 1970, hvor han med bidende satire beskrev, hvorledes bl.a. komponisten Leonard Bernstein holdt store velgørenhedsreceptioner for panterne i sin 13 værelses store penthouse-lejlighed på Park Avenue og havde været nødsaget til i aftenens anledning at give sin sorte butler fri og hyre hvide tjenere, som kunne servere de små delikate stykker Roquefort, som gæsterne kunne nyde, mens de beundrende og lidt skræmte kiggede på de fremmødte repræsentanter for Black Panther Party. ${ }^{5}$ Wolfe oplevede scenariet som et udtryk for radical chickness, hvor New York intelligentsiaen og den kulturelle elite kunne sole sig i egen selvfedme over at have de rigtige progressive meninger uden nødvendigvis selv at skulle besværes med eksempelvis at gå på gaden. Selvom der ikke er noget som helst af den uforpligtende glathed, som Wolfe excellerer i, over Derrida, så var den algerisk-franske filosof ikke desto mindre nervøs for, at Genets støttekomité risikerede at domesticere Jacksons og panternes kamp og gøre den til, hvad han kalder "en litterær affære". Som Derrida formulerer det i sit brev til Genet, han forfattede på en båd på vej til et foredragsarrangement i USA:

(f Ved kun at anklage en sag eller et tilfælde [...], risikerer man da ikke lidt at sætte et plaster på alt det, som de breve, du har introduceret [George Jacksons breve, som Genet skrev introduktion til], har revet op, og at reducere dette enorme anliggende til en mere eller mindre litterær, nok også forlagsmæssig, begivenhed, til en fransk, ja, parisisk, forestilling, som en intelligentsia, der var travlt beskæftiget med disse underskrifter, opfører for sig selv? Det er derfor, jeg endnu tøver med at deltage i det kollektive initiativ, som De har omtalt for mig. (Derrida 2007: 97)

Derrida var med andre ord skeptisk. Det betød ikke, at han ikke ville signere Genets appel, for det gjorde han. Og det betød heller ikke, at han ikke ville bidrage til den bog, Genet ville udgive til støtte for Jackson som opfølger til Soledad Brother. Men Derridas bidrag skulle tage form af et brev, hvori han redegjorde for sin tilbageholdenhed og pegede på det potentielt problematiske ved projektet. Som det fremgår af citatet, var Derrida utryg ved hele forehavendet, fordi han frygtede, det ville tage form af en nærmest rituel fordømmelse og afvisning, hvor franske intellektuelle, ham selv inklusive, med god samvittighed højlydt og med brask og bram i fuld offentlighed sagde fra. Men over for hvem? Forehavendet risikerede at blive "en fransk forestilling". Og det var ikke nok bare at tale fransk eller parisisk. Parisiske intellektuelle var (ofte) gode til at sige fra, men det drejede sig jo forhåbentlig ikke om dem, men om Jackson og de sortes kamp mod racisme og undertrykkelse. Eller hvad? Derrida følte tilsyneladende et behov for at undgå den grandiose selvretfærdige selviscenesættelse, hvorefter man med god samvittighed kunne læne sig tilbage efter at have sat sin signatur på en appel. Aktivismens selvgodhed, hvor man er sikker på, at man har gjort noget godt, taget stilling og gjort sit. Dette ville blot være en form for pral, hvor franske intellektuelle anklagende poserede uden for 


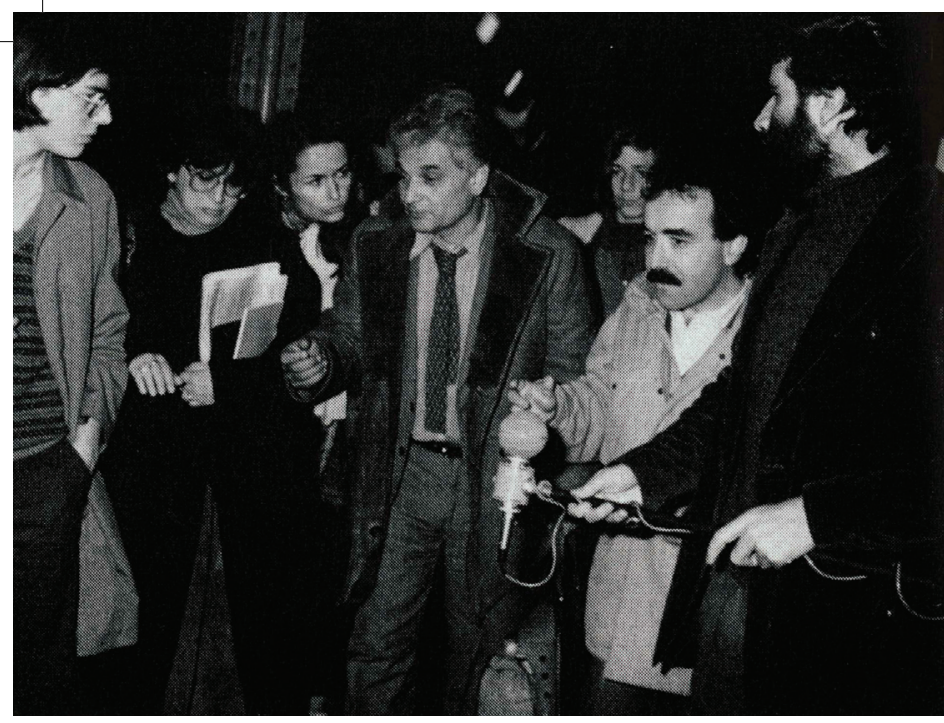

Derrida vender tilbage fra Prag efter at være blevet arresteret og tilbageholdt af det tjekkoslovakiske politi efter at have holdt møder med lokale dissidenter, 1982.

fængslet i en parisisk kulturoffentlighed, uden at være underlagt den hårde og brutale virkelighed, som Jackson var prisgivet. Det ville ikke ændre noget som helst, men blot bekræfte de allerede etablerede positioner: Fordi Jackson var sort, var han ingenting, var han i fængsel. Derrida og Genet derimod var frie til at engagere sig og sige fra. Den repræsentation havde Derrida besvær med at forlige sig med. Som han formulerer det: "Kommer vi nogensinde til at vide, hvem der fanger hvem på denne scene?" (ibid.).

Nej, det traditionelle politiske engagement var befængt med problemer for Derrida. Det var en form for sovepude. Vi er hér, de er dér. Vi er gode, de er onde. Den kollektive appel risikerede blot at reproducere den allerede etablerede intellektuelle offentlighed, som ikke havde problemer med at lade Barthes, Genet, Sollers, Derrida etc. stille sig op og proklamere deres støtte til Jackson og anklage USA for racisme. På den måde var den kollektive appel ifølge Derrida ikke tro mod objektet, men bekræftede det eksisterende, syede det sår sammen, som udgivelsen af Jacksons breve ellers havde åbnet. Problemet var jo, at det så igen var Genet og Derrida, forfatteren og filosoffen, der talte. Det er også derfor, Derrida var usikker på, om det var hensigtsmæssigt at betone Jacksons litterære evner, hvad Genet omtalte som hans "litterære talent". "[D] erfor er jeg bange for den påtrængenhed, hvormed man en dag kan tale om det, som du kalder 'poeten' Jacksons 'litterære talent'." (ibid.). Derrida ville på ingen måde benægte kvaliteten af Jacksons breve og pointerede også, at det var nødvendigt at bruge og gøre opmærksom på deres litterære kvaliteter. Men var det ikke at vaske Jackson ren at gøre ham til "poeten Jackson"? Vi kan genkende ham, hvis han er forfatter, vi kan forstå det, han siger, hvis han taler vores sprog. Logikken syntes i så fald at være, at kun hvis Jackson er som os, er forfatter, er hvid måske, en rigtig hvid, så kan han blive hørt. Derrida var opmærksom på og sensitiv over for sådanne eksklusionsmekanismer og den måde, sandhed produceres på af den dominerende diskurs; advarselslamperne blev tændt. Derfor var han nødsaget til at stille de pinlige og besværlige spørgsmål, selv til sin gode ven Genet, som han mindst af alle tiltroede onde motiver. Det var nødvendigt at stille disse spørgsmål, der truede med at trække tæppet væk under benene på engagementet og appellen. Derrida var nødsaget til at se nærmere på den udsigelsesposition, appellen etablerede. Hvilket subjekt var der tale om? Hvad var den alvorsfulde og pa- 
Pressekonference i UNESCO i Paris i forbindelse med publiceringen af bogen Pour Nelson Mandela, 1986.

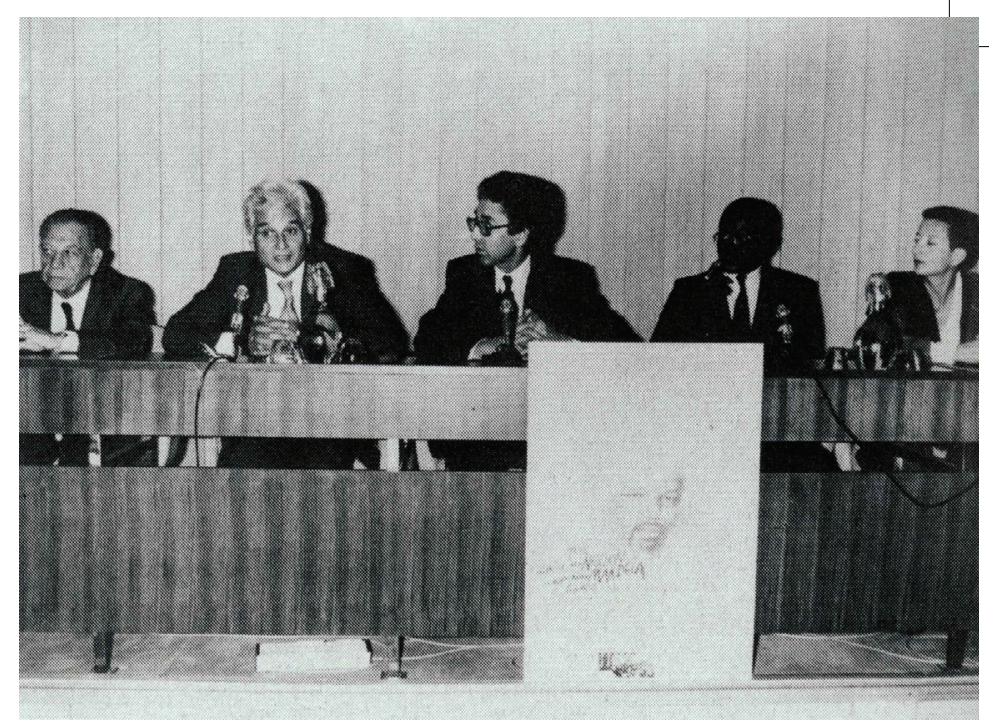

tetiske retorik i appellen udtryk for? Begæret efter at anklage var slet ikke uproblematisk, for hvad var forholdet mellem dette begær og en egentlig refleksion? Hvem artikulerede denne anklage og hvorfra? Det var nødvendigt at stille disse spørgsmål for Derrida. Det betød ikke, at han i nogen banal betydning af ordet trak sig tilbage fra det politiske engagement, snarere var der tale om, som Jean-Luc Nancy skriver, at han "med skarpsindighed og omtanke i den stærke betydning af ordet [...] fornemmede det nødvendige i at forskyde engagementet i forhold til kanoniske tvangsmæssigheder, det vil sige i forhold til identitetsmæssige tvangsmæssigheder" (Nancy: 68).

Det er nemlig ikke nok at fokusere på budskabet, at redde argumentet, som den disciplinære filosofi og den officielle historie eksempelvis gør det, hvorved den glemmer detaljerne. Detaljerne betyder noget, insisterer Derrida. Det er nødvendigt at være opmærksom på de små accenter og på konteksten. Ja, selvfølgelig signerer Derrida Genets appel, men han forsøger samtidig at forhøje indsatsen i sit brev, der blotlægger engagementets fælder og peger på risikoen for, at objektet forrådes undervejs. Dette er ikke ikke at agere politisk, det er snarere at blive ved, blive ved med at insistere og aldrig give, aldrig holde op, for engagementet er aldrig helt ovre. Det er ikke noget, der slutter på nogen ligefrem måde. Og risikoen ved at sætte signaturen på appellen er netop, at det så var det. Det komplekse er netop, at man, idet man signerer og siger 'Jeg, Jacques Derrida...', skal flytte sig for at gøre plads til den anden, til Jackson. Fra Jacques til Jack-son. Fra far til søn. Men det er altså også tvingende nødvendigt ikke at påtvinge Jackson et hegemonisk og instrumentelt sprog. Jackson skal ikke bare sættes fri, forvandles fra objekt til subjekt, det er samtidig nødvendigt at afvise forestillingen om at genskabe en undertrykt eller tabt identitet. Så nu er han fri. Nu har vi fast grund under fødderne. I så fald ville der ikke være sket andet, end at Jackson havde taget Derridas plads. Som om Jackson blot skal træde ind i eller realisere en allerede defineret rolle, som om der findes en allerede defineret subjektposition, han blot skal indtage. Som Gayatri Spivak, der med, ud over og i forlængelse af Derrida nok er den, der har arbejdet mest ihærdigt med disse problemer, formulerer det: "Det er dekonstruktionens største gave: At stille spørgsmålstegn ved det unders $\varnothing$ gende subjekts autoritet uden at paralysere ham, vedvarende forvandle umulighedsbetingelser til mulighedsbetingelser" (Spivak 1988: 201). ${ }^{6}$ Det er van- 
skeligt det her: Der sker en splittelse, Derrida siger fra over for undertrykkelsen, han stiller sig op som beskytter af Jackson, som hans opsynsbetjent, og kræver ham sat netop på fri fod, kræver, at Jackson er, kan være noget andet. Uden opsynsmand. Myndig. Og ikke blot forfatter og hvid, den samme identitet, men noget andet end "en parisisk forestilling".

64 Selv med den bedste vilje i verden, med den mest oprigtige moralske indignation over noget, der faktisk er uudholdeligt og uantageligt, ville man måske komme til at fængsle det igen, som man ønskede at befri. At tæmme et lovbrud. Nuvel, det har på en vis måde (og lad os ikke glemme den anden måde) allerede fundet sted: den sorte, der er anholdt og slavebundet af den hvide (den racistiske-kapitalistiske hvide), bliver så atter til noget andet end et afgrænset, ret- eller vrangvendt billede på sin herre. Han bryder ud af fangevogterens synsfelt og gør sig fri af sin tilstand som lærling. (Derrida 2007: 97)

Hvis vi et kort øjeblik zoomer lidt ud, er det tydeligt at se, hvorledes Derrida i disse år adskiller sig fra andre samtidige franske filosoffer, der på forskellig vis var engageret i politiske kampe. Derrida havde placeret sig underligt forskudt i forhold til den offentlige debat. Og det var sjældent, at han kom med åbne holdningstilkendegivelser til fordel for konkrete politiske eller sociale sager. Ikke at det ikke skete, Derrida støttede op om de studerende i Maj '68, men i sammenligning med mange andre forblev han relativt tilbagetrukken. Senere, i 1980'erne, rejste han til Prag og talte med tjekkoslovakiske dissidenter, og han meldte ud i forhold til Sydafrika og skrev en tekst om Mandela og demokrati. Og så begyndte han i 1990'erne mere systematisk at adressere mere direkte politiske emner som kapitalismen og skrev sine bøger om bl.a. Europa, Marx og venskabet. Men hele vejen og altså også i den ellers meget politisk dynamiske tid efter 1968 havde Derrida reservationer over for det traditionelle politiske engagement og var forsigtig i sammenligning med eksempelvis Foucault, Bourdieu eller Althusser. Hans tænkning var ikke en engageret tænkning, men snarere et opgør med den på det tidspunkt stadigvæk dominerende model for en sådan, nemlig Sartres engagerede intellektuelle, der ifølge Derrida var karakteriseret af ideologisk og filosofisk naivitet.7 Derridas reservation var en blandt flere samtidige måder at distancere sig fra Sartres forestilling om den intellektuelle som menneskehedens universelle bevidsthed. Foucaults "specifikke intellektuelle" var en anden. Begge kritikker var kendetegnet ved en voldsom afvisning af den humanisme og antropologisme, som Sartre abonnerede på. Sartres filosofiske antropologi og dens privilegering af mennesket blev underkastet kritisk analyse, og det eksistentielle subjekt viste sig med Foucault og Derrida at være en form, der produceres. Men hvor Foucault afsværgede filosofien og vendte sig mod det specifikke arbejde med eksempelvis indsatte og sindssyge, forblev Derrida knyttet til filosofien og var skeptisk over for idéen om, at historievidenskaben eller den specifikke intellektuelle som for Foucault, eller sociologien i Bourdieus tilfælde, skulle være mindre profetisk end Sartres eksistentialisme. Det ville være for nem en løsning. Og nemme løsninger er der ingen af hos Derrida. Som Barthes formulerede det i 1972, forårsager Derridas tænkning tværtimod "en form for uopholdelig beskadigelse af vores intellektuelle bekvemmelighed (den tilstand hvor vi styrker os 
ved det, som vi tænker)" (Barthes: 1417). ${ }^{8}$ Derfor vedblev Derrida stædigt at være filosof og valgte at bruge tid på møjsommeligt og omhyggeligt at analysere (u)mulighedsbetingelserne for engagementet og utrætteligt stille de besværlige spørgsmål om engagementets forsimplinger og reduktioner.

Engagementet var risikabelt, hvis ikke direkte problematisk, men det var ifølge Derrida ikke desto mindre nødvendigt. Det skrev han i teksten "'Il courait mort': Salut, salut. Notes pour un courrier aux Temps Modernes", forfattet i 1996 til et jubilæumsnummer af Les Temps Modernes i anledning af 50 året for grundlæggelsen af tidsskriftet. I artiklen artikulerer Derrida igen sine forbehold over for Sartres engagement, men forholder sig samtidig affirmativt til engagementet og til idéen om en uendelig ansvarlighed: "[Det er] Bydende nødvendigt at bevare ordet 'engagement', et smukt ord som stadig er helt nyt (løfte, væddemål og sprog, 'situation', uendelig ansvarlighed, kritisk frihed i forhold til alle apparater etc.), men måske modulere det i en delvist ny retning" (Derrida 1996: 40). ${ }^{9}$

Det er selvfølgelig efter Sartre også et spørgsmål om ansvarlighed, vi er konfronteret med her i 1971, hvor Genet orkestrerer støtten til Jackson. Hvordan kan man reagere på Jacksons sag? Der skal svares, handles, men der skal også lystres i betydningen være affirmativ over for det, der ytres. Det er et spørgsmål, som Derrida vendte tilbage til ved flere lejligheder senere i sit forfatterskab, hvor han hver gang betoner, at ansvaret ikke kan reduceres til hverken et program, en pligt, eller det modsatte som en intuition eller solipsisme. Derrida blev aldrig træt af at understrege, at ansvarlighedens mulighedsbetingelse er aporetisk: vi er konfronteret med den umulige mulighed af et generelt 'valg', der også er en 'personlig' afgørelse. Som han formulerer det i L'autre cap: "Jeg vil endda være så dristig at sige, at etik, politik og ansvarlighed, hvis der er nogen, vil altid være begyndt med erfaringen af [...] aporien" (Derrida 1991: 43). For hvis det blot drejer sig om at følge en allerede defineret plan, så vil vi aldrig foretage et valg (om ansvarlighed). Men hvis vi på den anden side aldrig skal tage hensyn til det politiske pres om at være ansvarlig over for noget, så vil afgørelsen ikke være andet end en form for selvvaliderende indfald eller grille. Der er således noget radikalt uafklaret ved ansvarligheden, der river den løs fra allerede formede figurer eller størrelser, og gør det umuligt at være tilstrækkeligt ansvarlig, at agere ansvarligt nok. Ansvarligheden lader sig ikke afslutte. Der

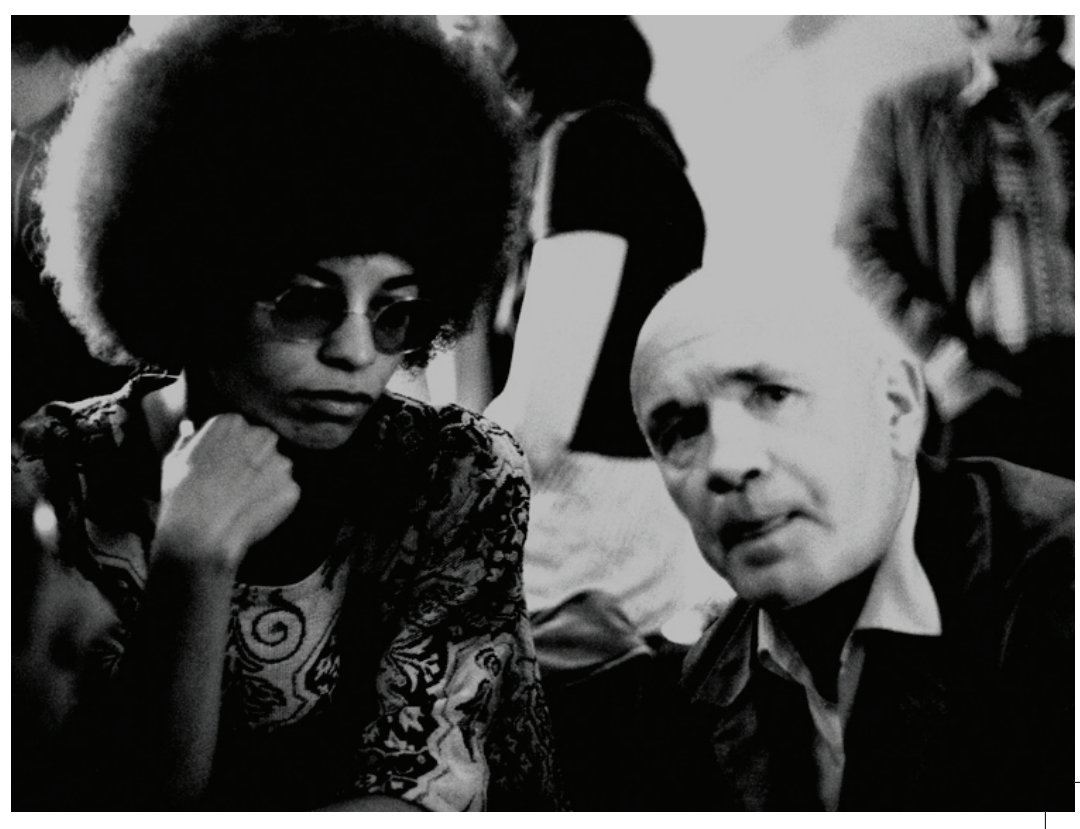




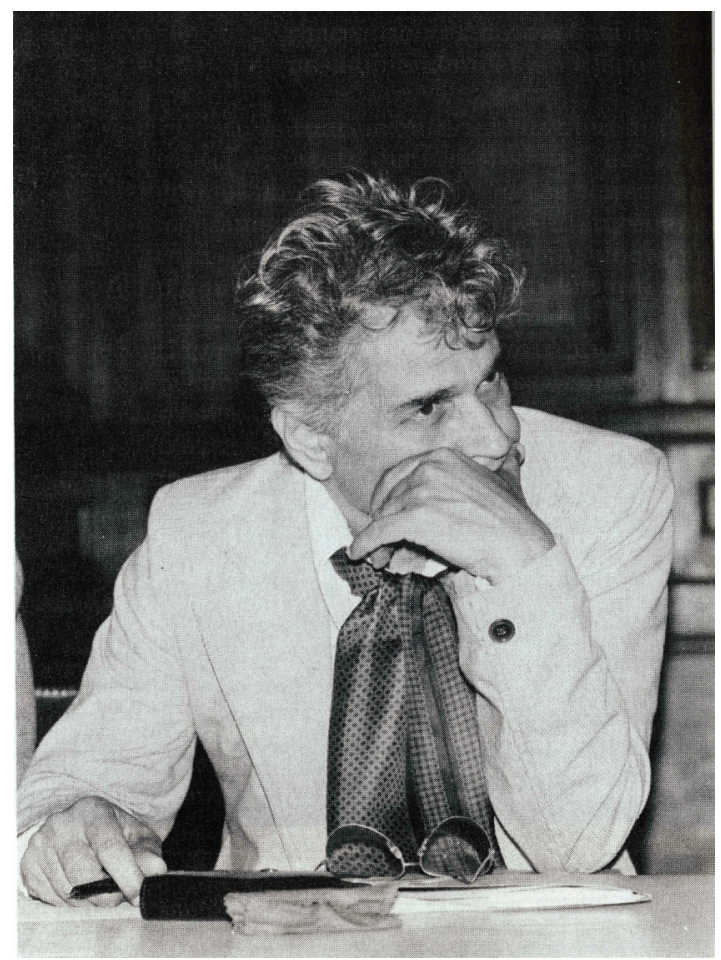

Derrida til konference på Sorbonne i 1979.

er ingen garantier. Hvis vi på forhånd vidste, hvad der skulle gøres, hvis viden kunne guide vores handlinger, så ville der ikke være nogen ansvarlighed. Der skal gøres noget, og det kan ikke vente, den enkelte er altid allerede engageret af og for den anden i en kontekst, vedkommende ikke er herre over. Men kun hvis konteksten er konstitutivt åben, kan den anden dukke frem som den anden.

Derrida kan altså ikke uden videre indfri det krav om politisk engagement, som Genet stiller, da det til en vis grad synes at abonnere på de "humanvidenskabelige diskurser", som Derrida netop kritisk spørger til og undersøger i sit filosofiske arbejde. Disse humanvidenskabelige diskurser, det være sig eksempelvis lingvistikken, sociologien eller antropologien, gør det tilsyneladende muligt at forklare traditionelle metafysiske problemer og blotlægge deres betingelser med henvisning til noget andet som sproget, samfundet eller den menneskelige natur. Ifølge Derrida sker der imidlertid det, at det begreb, der skal effektuere reduktionen og forklare metafysikken, selv indsættes i en transcendental position, der forbliver uforståelig for diskursen. Det begreb, der skal reducere filosofiens metafysiske påstande, er altså selv metafysisk. Kravet om et politisk engagement er et eksempel på en sådan operation, hvad Derrida i denne periode kalder "en metafysisk kontrabande", hvor det politiske og det politiske engagement udstyres med den transcendentalitet, det er meningen, det skal forklare. Den metafysiske operation består i at ville føre tingene tilbage til en simpel oprindelse, til et nærvær. En sådan operation er altid voldelig ifølge Derrida. Som både Rodolphe Gasché og Geoffrey Bennington har redegjort for, forholder Derridas egen tænkning sig til denne problemstilling ved at forsøge konstant at bevæge sig mellem et transcendentalt og et empirisk niveau uden at tildele det ene eller det andet forrang (jf Bennington; Gasché). Som det lyder i De la grammatologie: "Ved nødvendigvis at operere indefra, hente alle subversionens økonomiske og strategiske ressourcer i den gamle struktur, og endda 
låne dem i overensstemmelse med strukturen, dvs. uden at kunne isolere deres elementer og atomer, er de-konstruktionsforsøget altid på en måde offer for sit eget arbejde" (Derrida 1970: 73).

Derrida peger igen og igen på den vold, der er indlejret i det at reducere noget til en oprindelse, en tese eller et navn, når man er sikker i sin sag, har ret og udryddet tvivlen. Og hvad nu hvis oprindelsen er irreducerbart kompleks, spørger Derrida? Hvad nu hvis den simple oprindelse er en retrospektiv tilbageprojektering, og det ikke kan lade sig gøre at analysere oprindelsen? Hvis der ikke er nogen fast grund, på baggrund af hvilken engagementet finder sted, og hvis målet for engagementet ligeledes unddrager sig bestemmelse og viser sig at være mindst lige så komplekst? Så er det ikke længere muligt bare at stoppe op, at skabe ligevægt og etablere en komplet tilstedeværelse. Dekonstruktionen betyder, at såvel arkhe som telos mister deres soliditet, bliver åbne til alle sider. ${ }^{10}$ Metafysikkens tro på simple oprindelser og simple mål skal dekonstrueres, det gentager Derrida egensindigt og stædigt gennem hele sit forfatterskab. For uanset hvor nobelt endemålet tager sig ud, så er det altid en begrænsning, en aflivning, en reduktion. Derfor forsøger Derrida at gøre endemålet uendeligt. Og spørger Genet, om det er det rigtige mål, han har sat sig, og om det er den rigtige vej, han har udstukket? Her begynder de simple oppositioner mellem godt og ondt naturligvis at gå i opløsning, og ansvarligheden melder sig med kolossal kraft konfronteret med begivenhedens uforudsigelighed.

Og pludselig går det hurtigt. Den 21. august 1971, tre dage før George Jacksons retssag skal begynde, bliver han dræbt i San Quentin-fængslet, som han var blevet overført til. Ifølge fængselsvæsnet og myndighederne blev han skudt under et fængselsoprør, som han selv havde iværksat. Black Panther Party udlagde Jacksons død som det endelig forsøg på at få bugt med Jacksons kamp mod racisme og for frihed. Genet afviste også den officielle udlægning og skrev artiklen "The Americans kill off the Blacks" i Black Panther Newspaper i September 1971, hvor han ikke vil nedlade sig til at kalde Jackson amerikaner. Jackson var "landsmand med alle unge i alle nationer og alle de nationers folk, som bliver knust af USA" (Genet citeret i Sandarg: 280). Med Jacksons død blev Genets bogprojekt lagt på hylden, og Derridas brev lagt i skuffen. Udviklingen synes umiddelbart med ét at have overhalet såvel appellen, tilkendegivelsen som reservationen. Men det betød ikke, at Genet ikke utrætteligt fortsatte sin kamp for undertrykte folk, ligesom Derrida ufortrødent og ubønhørligt fortsatte sin analyse af engagementets nødvendighed og fælder. ${ }^{\text {II }}$

Tak til Carsten Juhl, Jesper Lohmann og Jacob Lund for hjælp og kommentarer til teksten.

\section{Noter}

I Jacques Derridas brev til Jean Genet, dateret den 20. august 1971, er delvist transskriberet i Derrida 2007: 96-97.

2 Indledningen fra den på dette tidspunkt Berkeley-baserede tyske filosof Herbert Marcuses Counterrevolution and Revolt fra 1972 gengiver noget af stemningen: "Den vestlige verden har nået et nyt trin i udviklingen. Nu kræver forsvaret for det kapitalistiske system, at kontrarevolu- 
tionen bliver organiseret, både i USA og andre steder i verden. De steder, hvor denne udvikling gør sig mest udpræget gældende, benytter den sig af nazi-regimets rædselsfulde metoder. [...] I USA går studenterne stadig i spidsen for den radikale protest, mordene på universiteterne i Jackson og Kent er et vidnesbyrd om studenternes historisk rolle. Militante negre betaler med deres liv: Malcolm X, Martin Luther King, Fred Hampton, George Jackson. Højesterets nye sammensætning har institutionaliseret reaktionens fremgang, og mordene på Kennedy-brødrene viser, at end ikke liberale kan vide sig sikre, hvis de virker for liberale..." (Marcuse: 9-10).

3 For en præsentation af George Jackson, se Mann.

4 For en præsentation af Genets foredragsturné og hans engagement i Black Panther Party, se Sandarg.

5 Wolfe udstiller spottende og veloplagt kontrasten mellem det militante Black Panther-look og velgørenhedsmiddagens overklassestil: "Vil den store Black Panther, der står dér i gangen og giver hånden til Felicia Bernstein selv, ham med den sorte læderfrakke og de sorte briller og den helt utrolige afro - i total fuzzy-wuzzy-størrelse - vil han, en Black Panther, tage et stykke Roquefort-ost rullet i knuste nødder fra serveringsbakken, fra en stuepige i uniform, og bare proppe det ned i svælget uden så meget som at miste en stavelse af Felicias perfekte Mary Astortale" (Wolfe: 28).

6 En lang række af Spivaks tekster behandler disse problemer, eksempelvis det tredje kapitel af $A$ Critique of Postcolonial Reason: Towards a History of the Vanishing Present, der indeholder en revideret version af den vigtige tekst “Can the Subaltern Speak?", 198-311.

7 Denne kritik kommer eksemplarisk til udtryk i teksten "Les fins de l'homme" (Derrida 1972).

8 I samme brev dateret den 21. maj 1972 forklarer Barthes, hvorfor han desværre ikke kan bidrage til et temanummer af Les Lettres humaines om Derrida. Han har ikke tid.

9 Sartre skriver om den uendelige ansvarlighed i essayet "Litteraturens sociale funktion" ["Présentation”, 1945], oversat af Niels Egebak, i Situationer. Udvalgte essays, København: Gyldendal, 1964, 19-36.

Io For lige at skære det ud i pap: Derrida er altså allerede på dette tidspunkt i den tidlige fase af sit forfatterskab engageret i en dekonstruktion af det politiske engagement, en operation der muligvis bliver tydeligere i 1990'erne med de såkaldt 'politiske bøger' om venskab, slyngler og Internationalen, men som altså allerede er til stede tidligere. Det er derfor spørgsmålet, om det er muligt at skelne mellem en tidlig og sen Derrida med henvisning til det politiske. Snarere er der nok tale om, at Derrida i bøgerne fra 1960'erne, 1970'erne og 1980'erne fokuserer på oprindelsen og i dem fra 1990'erne på endemålet. På intet tidspunkt tager dekonstruktionen af engagementet form af udviklingen af en egentlig politisk teori; Derrida peger netop på det ved engagementet, der overskrider en traditionel viden (og derfor ikke kan sættes på formel som en ny politik eller etik) og konstant tvinger os til at handle og permanent genoverveje vores valg. Usikkerheden forbliver med en lidet derridask vending essentiel, og derfor skal engagementet hele tiden genopfindes på ny.

II Genet og Derrida forblev venner, og Derrida skriver i 1974 værket Glas om Genet (og Hegel). Men det er en anden historie.

\section{Litteratur}

Barthes, Roland (1994): “Lettre à Jean Ristat”, i CEuvres complétes. Vol. II, Paris: Éditions du Seuil, 1417. Bennington, Geoffrey (1991): Derrida, Paris: Éditions du Seuil.

Derrida, Jacques (1970): Om grammatologi [De lagrammatologie, 1967], oversat af Lars Bonnevie \& Per Aage 
Derrida, Jacques (1972): “Les fins de l'homme”, i Marges de la philosophie, Paris: Les Éditions de Minuit, 129-164.

Derrida, Jacques (1991): L'autre cap, Paris: Les Éditions de Minuit.

Derrida, Jacques (1996): “Il courait mort': Salut, salut. Notes pour un courrier aux Temps Modernes”, i Les Temps Modernes, nr. 587, 7-54.

Derrida, Jacques (2007): “Trésors d'archives: Jacques Derrida à Jean Genet” [1971], i Magazine Littéraire, nr. 464, 96-97.

Gasché, Rodolphe (1986): The Tain of the Mirror: Derrida and the Philosophy of Reflection, Cambridge, MA \& London: Harvard University Press.

Genet, Jean (2007): “Appel pour un comité de soutien aux militants politiques noirs emprisonnés” [1971], optrykt i “Trésors d'archives: Jacques Derrida à Jean Genet”, i Magazine Littéraire, nr. 464, 96.

Jackson, George (1970): Soledad Brothers: The Prison Letters of George Jackson, New York: Coward McCann.

Marcuse, Herbert (1974): Kontrarevolution og venstrefløj [Counterrevolution and Revolt, 1972], oversat af Merete Ries, København: Gyldendal.

Mann, Eric (1974): Comrade George: An Investigation into the Life, the Political Thought, and Assassination of George Jackson, New York: Harper \& Row.

Nancy, Jean-Luc (2007): "L'indépendance de l'Algérie et l'indépendance de Derrida", i Cités, nr. 30, 6570.

Sandarg, Robert (1986): “Jean Genet and the Black Panther Party”, i Journal of Black Studies, nr. 3, 269282.

Sartre, Jean-Paul (1964): "Litteraturens sociale funktion" ["Présentation”, 1945], oversat af Niels Egebak, i Situationer. Udvalgte essays, København: Gyldendal, 19-36.

Spivak, Gayatri Chakravorty (1988): "Subaltern Studies: Deconstructing Historiography" [1985], i In Other Worlds: Essays in Cultural Politics, New York \& London: Routledge, 197-221.

Spivak, Gayatri Chakravorty (1999): A Critique of Postcolonial Reason: Towards a History of the Vanishing Present, Cambridge, MA \& London: Harvard University Press.

Wolfe, Tom (1970): “Radical Chic: That Party at Lenny's", i New York Magazine, 8. juni, 27-56.

Jean Genet sammen med Allen Ginsberg og William S. Burroughs til demokraternes konvent i Chicago, 1968

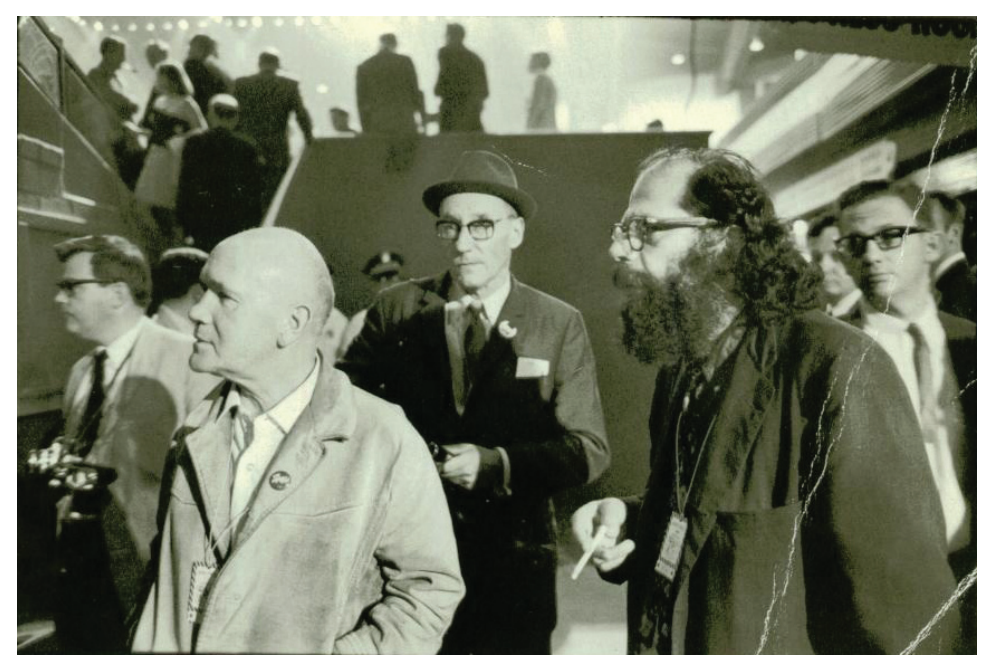

